Sains Malaysiana 50(9)(2021): 2499-2510

http://doi.org/10.17576/jsm-2021-5009-01

\title{
Influence of Various Gauge Lengths, Root Spacing and Root Numbers on Root Tensile Properties of Herbaceous Plants
}

(Pengaruh Pelbagai Panjang Tolok, Jarak Akar dan Nombor Akar pada Sifat Tegangan Akar Tumbuhan Herba)

\author{
ChaObO ZHANG*, XiAOYU MA, YATING LIU \& JING JiANG
}

\begin{abstract}
The mechanical properties of root system play an important role in soil reinforcement by plants. Root tensile properties are affected by many factors. It is necessary to explore the mechanical properties of root system and the influencing factors. In this study, tensile tests were conducted on roots of Kochia scoparia (L.) Schrad and Artemisia sacrorum Ledeb to study root tensile properties, including maximum tensile force, tensile strength and elastic modulus under the three factors, gauge length $(50,100,150$, and $200 \mathrm{~mm})$, root spacing $(0,1$, and $2 \mathrm{~cm})$ and root number (single root, double roots, and triple roots). The results showed that the maximum tensile force, tensile strength, and elastic modulus of the roots decreased with increasing gauge length in power functions. Under $100 \mathrm{~mm}$ gauge length, the maximum tensile force, tensile strength and elastic modulus decreased with increasing root spacing, but the effect of root spacing considered in this study on the maximum tensile force and tensile strength was not significant. Besides, with increasing root number, the maximum tensile force increased, tensile strength, and elastic modulus decreased. These findings stretched our understanding of the relationship between gauge length, root spacing and root number on root tensile characteristics, and provided the necessary data basis for root tensile properties and soil reinforcement by plants.
\end{abstract}

Keywords: Gauge length; root mechanical properties; root number; root reinforcement; root spacing

\section{ABSTRAK}

Sifat mekanik sistem akar memainkan peranan penting dalam pengukuhan tanah oleh tanaman. Sifat tegangan akar dipengaruhi oleh banyak faktor. Adalah perlu untuk mengkaji sifat mekanik sistem akar dan faktor yang mempengaruhinya. Dalam kajian ini, ujian tegangan dilakukan pada akar Kochia scoparia (L.) Schrad dan Artemisia sacrorum Ledeb untuk mengkaji sifat tegangan akar, termasuk daya tegangan maksimum, kekuatan tegangan dan modulus elastik di bawah tiga faktor, panjang tolok (50, 100, 150 dan 200 mm), jarak akar (0, 1 dan $2 \mathrm{~cm})$ dan nombor akar (akar tunggal, akar berganda dan akar tiga). Hasil kajian menunjukkan bahawa daya tegangan maksimum, kekuatan tegangan dan modulus elastik akar menurun dengan peningkatan panjang pengukur dalam fungsi daya. Di bawah panjang tolok $100 \mathrm{~mm}$, daya tarik maksimum, kekuatan tegangan dan modulus elastik menurun dengan peningkatan jarak akar, tetapi pengaruh jarak akar yang dipertimbangkan dalam kajian ini terhadap daya tegangan maksimum dan kekuatan tegangan tidak signifikan. Selain itu, dengan bertambahnya bilangan akar, daya tarik maksimum meningkat, kekuatan tegangan dan modulus elastik menurun. Penemuan ini meluaskan pemahaman kami tentang hubungan antara panjang tolok, jarak jarak dan nombor akar pada ciri tegangan akar dan menyediakan asas data yang diperlukan untuk sifat tegangan akar dan pengukuhan tanah oleh tanaman.

Kata kunci: Jarak akar; nombor akar; panjang tolok; peneguhan akar; sifat mekanikal akar

\section{INTRODUCTION}

With the construction of large-scale infrastructure, soil erosion is becoming one of the most serious environment problems (Feng et al. 2019). Serious soil erosion and landslides are also the concentrated reflection of ecological deterioration in the developing countries, such as China, threatening national ecological security and restricting the economic and social development. Traditional measures of civil engineering protection are not the best choices which cannot be widely used in large areas because they are not 
environmentally-friendly methods with high costs (Abdi 2018). Plant measures are the most effective measures which take into account both economic benefits and environmental benefits, and can respond dynamically to environmental variations (Bischetti et al. 2010; Jones $\&$ Hanna 2004). The network of criss-cross roots tightly binds soil particles, which can effectively inhibit shallow soil erosion. Root-soil composite consequently formed can increase the sliding resistance of soil, thereby improving the stability of slopes (Cohen \& Schwarz 2017; Hubble et al. 2013; Stokes et al. 2014). When root-soil composite is subjected to shear action, roots can mobilize their tensile properties to reinforce soil (De Baets et al. 2008). During the shear process, roots usually fail in three types: breaking, slipping and stretching (Pollen 2007; Tosi 2007). Root tensile strength can be fully exerted when roots are broken, but under slipping and stretching failure types, root tensile strength does not perform at full capacity, and root tensile properties can be characterized by elastic modulus (Sanchez-Castillo et al. 2017; Tosi 2007). Root tensile properties therefore play a key role in evaluating root reinforcement and selecting vegetation for soil reinforcement by plants. At present, the research methods of root tensile properties mainly use the laboratory single root tensile tests. Much work to date has focused on quantifying root tensile properties considering plant species, root diameter, root length, root water content, and soil environment. Different species have different mechanical properties due to their different organizational structures and chemical composition of roots (Hudek et al. 2017; Zavala-Gonzalez et al. 2019). For an individual species, the relation between root tensile strength and root diameter has been reported in almost all existed studies which were concerned with root mechanical reinforcement, and negative power laws are commonly used to explain the relation for various plant species. A small amount of researches were also conducted on root length, which show that root tensile strength decrease with increasing gauge length (Yang et al. 2016; Zhang et al. 2012). Root moisture content also affects the strength of roots. A slight loss of root moisture content could increase root tensile strength (Boldrin et al. 2018; Hales \& Miniat 2017). Mahannopkul and Jotisankasa (2019) and Zhang et al. (2019) also observed the phenomenon that root tensile strength decreased linearly with increasing root moisture content. In addition, root tensile properties are also affected by soil environment (Hollis \& Turner 2019). Although these studies have acquired useful conclusions of root tensile properties and the effects of the facts on the properties, they mainly focused on the tensile tests of single root. The actual effect of root reinforcement in soil is exerted not only by independent individual roots but also by interaction between multiple roots. Recent studies such as Liu et al. (2018) and Ni et al. (2019) showed that planting spacing or density had a significant impact on root tensile characteristics and slope stability. Liu et al. (2018) pointed out that no significant difference of root tensile properties was observed between the three planting densities of maize $\left(4.5 \times 10^{4}, 6.75 \times 10^{4}\right.$, and $9.0 \times 10^{4}$ plants $\left.\mathrm{ha}^{-1}\right)$ at the tenth leaf visible stage. During the grain-filling stage, the maximum tensile force of nodal roots on upper nodes was significantly affected by the planting density, and it decreased with increasing planting density. Ni et al. (2019) also found that plant spacing affected root tensile strength, especially in fine roots (i.e. diameter $<2 \mathrm{~mm}$ ), and the closer plant spacing resulted in the lower root tensile strength. Therefore, root spacing and root number should affect soil reinforcement by plant roots, but the detailed effect of the two factors is still unclear.

Therefore, the aims of the study were to quantify the effect of gauge length, root spacing, and root number on root tensile property, provide a data basis of root mechanical properties for root reinforcement in the hilly area in North China, and get some useful suggestions for root tensile tests.

\section{MATERIALS AND METHODS}

\section{STUDY AREA}

The roots tested were excavated from the west mountain of Taiyuan city, Shanxi Province, China. The mountain is located at $112^{\circ} 9^{\prime} \sim 112^{\circ} 24^{\prime} 49^{\prime \prime} \mathrm{E}, 37^{\circ} 40^{\prime} \sim 37^{\circ} 53^{\prime} 57^{\prime}{ }^{\prime} \mathrm{N}$, which is in the area of the Lvliang Mountain with an average altitude of $1400 \mathrm{~m}$. The main soil type is less accompanied with a small amount of brown soil. Around the roots excavated, the soil $\mathrm{pH}$ was 7.2 , and the density was $1.25 \mathrm{gcm}^{-3}$. The region is in a temperate continental monsoon climate, with cold and dry winters and hot and humid summers. The average annual precipitation is 470 $\mathrm{mm}$, mainly in June and August, accounting for $80 \%$ of the annual precipitation. The average annual temperature is $10{ }^{\circ} \mathrm{C}$, and the average frost-free period is 202 days.

\section{ROOT SELECTION}

Two widely spread species, Kochia scoparia (Figure 1) and Artemisia sacrorum (Figure 2), were selected as the 
research objects, and their roots were excavated in May 2019. Ten uniform plants were selected randomly for each species. The roots were dug with entire excavation method, and then root samples were carefully packed with sealing bags to keep them fresh during transportation.

The collected roots were cleaned with a brush and trimmed with a scissor, and placed in sealing bags and stored in a refrigerator at $4{ }^{\circ} \mathrm{C}$. Before root tensile tests, the diameter of each root was measured and then grouped according to the measured diameter to ensure that the results were not affected by the different distribution of root diameter. The tensile tests were conducted under the three factors: gauge length, root spacing and root number. Four levels of gauge length $(50,100,150$, and $200 \mathrm{~mm}$ ) with single root, three levels of root spacing $(0$, 1 , and $2 \mathrm{~cm}$ ) with double roots in $100 \mathrm{~mm}$ gauge length, and three levels of root number (single root, double roots and triple roots) with $100 \mathrm{~mm}$ gauge length were set in the tests.

\section{TENSILE TESTS}

The tensile tests were carried out using a WDW-5 Universal Testing System (UTS, Changzhou Sanfeng Instrument Technology Co., Ltd, Changzhou, China). The instrument is able to generate the tensile force, to measure the load and displacement and to acquire the relevant data automatically. Root tensile properties, including peak tensile force, tensile strength and elastic modulus were measured. A load cell with a maximal capacity (FN) of $10.0 \mathrm{kN}$ and resolution of $0.0001 \% \mathrm{FN}$ was used. Strain rate $100 \mathrm{~mm} \mathrm{~min}^{-1}$ was set in the tests. To prevent the roots from slipping out of the clamps of the UTS and to reduce the possibility of root breaking by over tightening of the clamp, the two ends of the root were wound with medical tape in $25 \mathrm{~mm}$ length. Finally, failures occurring in the middle or near the middle of the roots were considered as valid results (Figure 3 ). The diameters of the roots were measured every $25 \mathrm{~mm}$ along the roots with a digital caliper, and each position was measured three times. The mean value of all positions was taken as the diameter of a root. Root tensile strength $(P)$ was calculated by the formula:

$$
P=\frac{4 F}{\pi D^{2}}
$$

where $F$ is the maximum force to root breakage $(\mathrm{N})$ and $D$ is the average root diameter $(\mathrm{mm})$.
The elastic modulus $(E)$ was calculated by the following formula:

$$
E=\frac{P}{\varepsilon}
$$

where $P$ is tensile strength and $\varepsilon$ is tensile strain, which equals to the ratio of the change in sample length to the original length.

\section{DATA ANALYSIS}

The data were analyzed using SPSS 20.0 for Windows. The normality of data was first verified and ensured that the data met the normal distribution. The differences of root tensile force, tensile strength, elastic modulus between the different levels of gauge length, root spacing, and root number were analyzed using one-way analysis of variance (ANOVA). The significant influence of the three factors on tensile properties was at 0.05 level. The figures were drawn using the Microsoft Excel ${ }^{\text {TM }} 2007$.

\section{RESULTS}

\section{GAUGE LENGTH}

Totally 219 samples of $K$. scoparia and 144 samples of A. sacrorum in gauge lengths 50,100, 150, and 200 $\mathrm{mm}$ were tested in this experiment. The success rate was between $25.97 \%$ and $67.65 \%$, and increased with gauge length. No significant difference of root diameter was observed between the four-gauge lengths for the two species (Table 1).

Root tensile force of $K$. scoparia and A. sacrorum decreased with increasing gauge length in power functions (Figure 4(a)). Among the four levels of gauge length, significant difference in tensile force was only observed between 50 and $200 \mathrm{~mm}$. For K. scoparia and A. sacrorum, the maximum tensile force was $9.49 \pm 1.62$ and $16.12 \pm 2.24 \mathrm{~N}$, respectively, under $50 \mathrm{~mm}$, and the minimum tensile force was $5.96 \pm 0.95$ and $10.92 \pm 1.49 \mathrm{~N}$, respectively, under $200 \mathrm{~mm}$. The minimum was reduced by $37.20 \%$ and $32.26 \%$ for K. scoparia and A. sacrorum compared with the maximum.

Root tensile strength gradually decreased with increasing gauge length, and a power function relationship was observed between them (Figure 4(b)). Gauge length significantly affected root tensile strength $(\mathrm{P}<0.05)$. For $K$. scoparia and $A$. sacrorum, the 
maximum tensile strength was $19.92 \pm 2.00$ and $19.91 \pm 1.56$ $\mathrm{MPa}$, respectively, under $50 \mathrm{~mm}$, and the minimum tensile strength was $12.16 \pm 1.15$ and $13.73 \pm 1.04 \mathrm{MPa}$, respectively, under $200 \mathrm{~mm}$.

The power law relationships were observed between gauge length and elastic modulus of the roots (Figure 6). The elastic modulus decreased with increasing gauge length, and there was no significant difference of the elastic modulus between the gauge length treatments (Figure 4(c)). The elastic modulus was within the range of 154.34-167.13 and 213.63-221.41 MPa for K. scoparia and $A$. sacrorum, respectively. Under the same gauge length, the elastic modulus of $A$. sacrorum was greater than that of $K$. scoparia.

\section{ROOT SPACING}

In root spacing treatments, a total of 172 groups were studied for K. scoparia, and 190 groups for A. sacrorum. The success rate was $25.71 \%-37.50 \%$ and $27.94 \%-38.60 \%$ for $K$. scoparia and A. sacrorum, respectively. Root diameter ranged from 0.38 to $1.22 \mathrm{~mm}$ for $K$. scoparia and 0.59 to $1.48 \mathrm{~mm}$ for $A$. sacrorum. Root diameter refers to the average diameter of the two roots. In each set of the experiments, the diameters of each measuring point of the two roots we selected were as close as possible to each other, and the average diameter of each root was close to the average diameter of the two roots. No significant difference of average diameter was observed between the root spacing groups (Table 2).

Root tensile force of $K$. scoparia and A. sacrorum decreased with increasing root spacing (Figure 5(a)). No significant difference of root tensile force was observed between the three-root spacing at 0,1 , and $2 \mathrm{~cm}$. For $K$. scoparia, compared with spacing of $0 \mathrm{~cm}$, root tensile force decreased by $2.24 \%$ and $8.49 \%$ under root spacing of 1 and $2 \mathrm{~cm}$. For A. sacrorum, root tensile force decreased by $8.25 \%$ and $8.92 \%$ when root spacing increased from $0 \mathrm{~cm}$ to $1 \mathrm{~cm}$ and $2 \mathrm{~cm}$.

A negative relationship was showed between root spacing and tensile strength (Figure 5(b)). Root tensile strength decreased with increasing root spacing, and there is no significant difference of root tensile strength between different root spacing. Compared with root spacing $0 \mathrm{~cm}$, root tensile strength of spacing 1 and 2 $\mathrm{cm}$ decreased by $17.12 \%$ and $19.56 \%$, respectively, for K. scoparia, and decreased by $1.70 \%$ and $10.91 \%$ for $A$. sacrorum.
The elastic modulus decreased with increasing root spacing (Figure 5(c)). The elastic modulus was $236.16 \pm 31.40,145.56 \pm 17.06$ and $129.03 \pm 12.39 \mathrm{MPa}$ under the three different levels root spacing for $K$. scoparia, and 196.29 $\pm 16.78,194.70 \pm 20.13$ and $182.66 \pm 25.83 \mathrm{MPa}$ for $A$. sacrorum. The elastic modulus of the spacing of 1 and $2 \mathrm{~cm}$ was $38.36 \%$ and $45.36 \%$ lower than that of the spacing of $0 \mathrm{~cm}$, respectively. Significant difference of elastic modulus was only observed between 0 and $1 \mathrm{~cm}, 0$ and $2 \mathrm{~cm}$ for $K$. scoparia, while no significant difference was observed between 1 and $2 \mathrm{~cm}$ for $K$. scoparia and among the three spacing levels for $A$. sacrorum.

\section{ROOT NUMBER}

207 groups of K. scoparia roots and 156 groups of $A$. sacrorum roots were studied under the three levels of root numbers, 1,2 , and 3 . The success rates were $33.33 \%$, $20.00 \%$ and $18.57 \%$ for $K$. scoparia roots, and $46.51 \%$, $36.54 \%$, and $32.79 \%$ for $A$. sacrorum roots under the three numbers, 1,2 , and 3 . There were no significant differences of average diameters between different root numbers (Table 3 ).

Root tensile force increased with the increase of the root number (Figure 6(a)). Compared with tensile force of single-root tests, tensile force of double-root tests and triple-root tests increased by $104 \%$ and $140 \%$, respectively, for K. scoparia, and increased by $71 \%$ and $89 \%$ for A. sacrorum. Tensile force of single-root tests was significantly different from those of double-root tests and triple-root tests, but there was no significant difference between double-root tests and triple-root tests. Under the same root number, tensile force of $A$. sacrorum was $2.15,1.81$ and 1.73 times greater than that of $K$. scoparia. Root tensile strength of both species decreased with increasing root number, but no significant difference of the tensile strength was observed between different root numbers (Figure 6(b)).

Root elastic modulus decreased with increasing root number (Figure 6(c)). Compared with single-root tests, elastic modulus of double-root tests and triple-root tests decreased by $29 \%$ and $31 \%$ for $K$. scoparia and decreased by $11 \%$ and $40 \%$ for $A$. sacrorum. The elastic modulus of single-root tests was significantly greater than that of triple-root tests. 
TABLE 1. The number of samples and root diameter distribution in different gauge lengths

\begin{tabular}{|c|c|c|c|c|c|c|}
\hline Plant species & $\begin{array}{l}\text { Gauge length/ } \\
\mathrm{mm}\end{array}$ & $\begin{array}{c}\text { Total samples/ } \\
\text { groups }\end{array}$ & $\begin{array}{l}\text { Successful samples/ } \\
\text { groups }\end{array}$ & $\begin{array}{l}\text { Success } \\
\text { rate } / \%\end{array}$ & $\begin{array}{l}\text { Diameter range/ } \\
\mathrm{mm}\end{array}$ & $\begin{array}{c}\text { Average diameter/ } \\
\mathrm{mm}\end{array}$ \\
\hline \multirow{4}{*}{ Kochia scopa } & 50 & 77 & 20 & $25.97 \%$ & $0.46-1.21$ & $0.73 \pm 0.05 \mathrm{a}$ \\
\hline & 100 & 68 & 23 & $33.82 \%$ & $0.46-1.17$ & $0.71 \pm 0.04 a$ \\
\hline & 150 & 42 & 20 & $47.62 \%$ & $0.49-1.14$ & $0.74 \pm 0.04 \mathrm{a}$ \\
\hline & 200 & 32 & 20 & $62.50 \%$ & $0.47-1.19$ & $0.76 \pm 0.04 \mathrm{a}$ \\
\hline & 50 & 40 & 16 & $40.00 \%$ & $0.70-1.34$ & $0.99 \pm 0.04 \mathrm{a}$ \\
\hline Artemisia & 100 & 32 & 18 & $56.25 \%$ & $0.72-1.26$ & $1.01 \pm 0.04 \mathrm{a}$ \\
\hline \multirow[t]{2}{*}{ sacrorum } & 150 & 34 & 23 & $67.65 \%$ & $0.69-1.37$ & $1.00 \pm 0.04 \mathrm{a}$ \\
\hline & 200 & 38 & 19 & $50.00 \%$ & $0.74-1.34$ & $0.99 \pm 0.05 \mathrm{a}$ \\
\hline
\end{tabular}

TABLE 2. The number of samples and root diameter distribution in different root spacing groups

\begin{tabular}{|c|c|c|c|c|c|c|}
\hline Plant species & $\begin{array}{c}\text { Root spacing/ } \\
\mathrm{cm}\end{array}$ & $\begin{array}{c}\text { Total samples/ } \\
\text { groups }\end{array}$ & $\begin{array}{l}\text { Successful samples/ } \\
\text { groups }\end{array}$ & $\begin{array}{l}\text { Success } \\
\text { rate } / \%\end{array}$ & $\begin{array}{c}\text { Diameter range/ } \\
\mathrm{mm}\end{array}$ & $\begin{array}{c}\text { Average diameter/ } \\
\mathrm{mm}\end{array}$ \\
\hline & 0 & 70 & 18 & $25.71 \%$ & $0.40-1.22$ & $0.76 \pm 0.06 \mathrm{a}$ \\
\hline \multirow[t]{3}{*}{ Kochia scoparia } & 1 & 54 & 17 & $31.48 \%$ & $0.38-1.16$ & $0.76 \pm 0.05 \mathrm{a}$ \\
\hline & 2 & 48 & 18 & $37.50 \%$ & $0.40-1.16$ & $0.74 \pm 0.05 \mathrm{a}$ \\
\hline & 0 & 65 & 24 & $36.92 \%$ & $0.59-1.46$ & $0.94 \pm 0.05 a$ \\
\hline \multirow{2}{*}{$\begin{array}{l}\text { Artemisia } \\
\text { sacrorum }\end{array}$} & 1 & 57 & 22 & $38.60 \%$ & $0.59-1.46$ & $0.95 \pm 0.05 a$ \\
\hline & 2 & 68 & 19 & $27.94 \%$ & $0.60-1.48$ & $1.01 \pm 0.06 \mathrm{a}$ \\
\hline
\end{tabular}

TABLE 3. The number of samples and root diameter distribution in different root number

\begin{tabular}{ccccccc}
\hline Plant species & Root number & $\begin{array}{c}\text { Total samples/ } \\
\text { groups }\end{array}$ & $\begin{array}{c}\text { Successful samples/ } \\
\text { groups }\end{array}$ & $\begin{array}{c}\text { Success } \\
\text { rate/\% }\end{array}$ & $\begin{array}{c}\text { Diameter range/ } \\
\text { mm }\end{array}$ & $\begin{array}{c}\text { Average diameter/ } \\
\text { mm }\end{array}$ \\
\hline \multirow{2}{*}{ Kochia scoparia } & 1 & 72 & 24 & $33.33 \%$ & $0.38-1.17$ & $0.69 \pm 0.04 \mathrm{a}$ \\
& 2 & 65 & 13 & $20.00 \%$ & $0.38-1.12$ & $0.73 \pm 0.06 \mathrm{a}$ \\
& 3 & 70 & 13 & $18.57 \%$ & $0.38-1.18$ & $0.69 \pm 0.07 \mathrm{a}$ \\
\hline \multirow{2}{*}{ Artemisia } & 1 & 43 & 20 & $46.51 \%$ & $0.63-1.25$ & $0.94 \pm 0.04 \mathrm{a}$ \\
sacrorum & 2 & 52 & 19 & $36.54 \%$ & $0.59-1.30$ & $0.92 \pm 0.05 \mathrm{a}$ \\
& 3 & 61 & 20 & $32.79 \%$ & $0.58-1.30$ & $0.88 \pm 0.05 \mathrm{a}$ \\
\hline
\end{tabular}




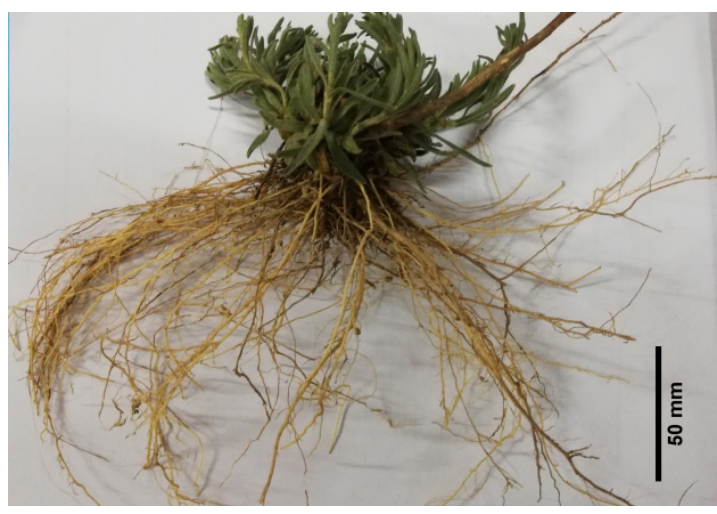

FIGURE 1. Kochia scoparia roots

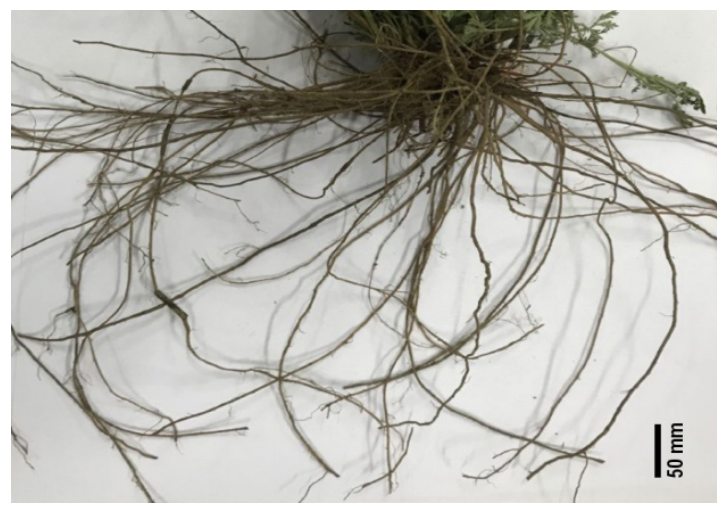

FIGURE 2. Artemisia sacrorum roots

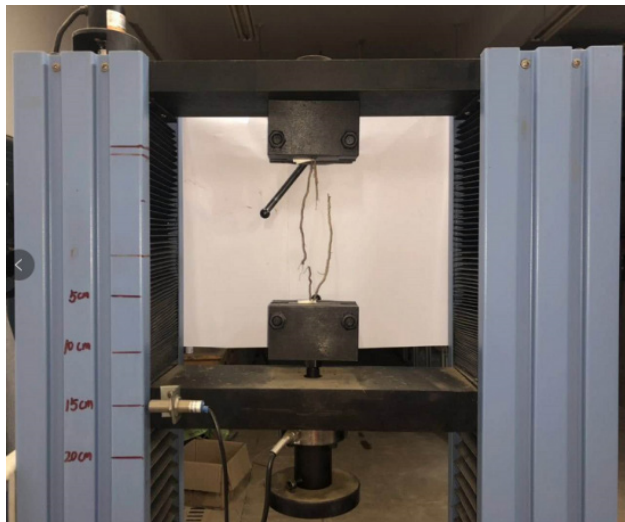

FIGURE 3. Example of a valid test of root breakage during double-root tensile tests 


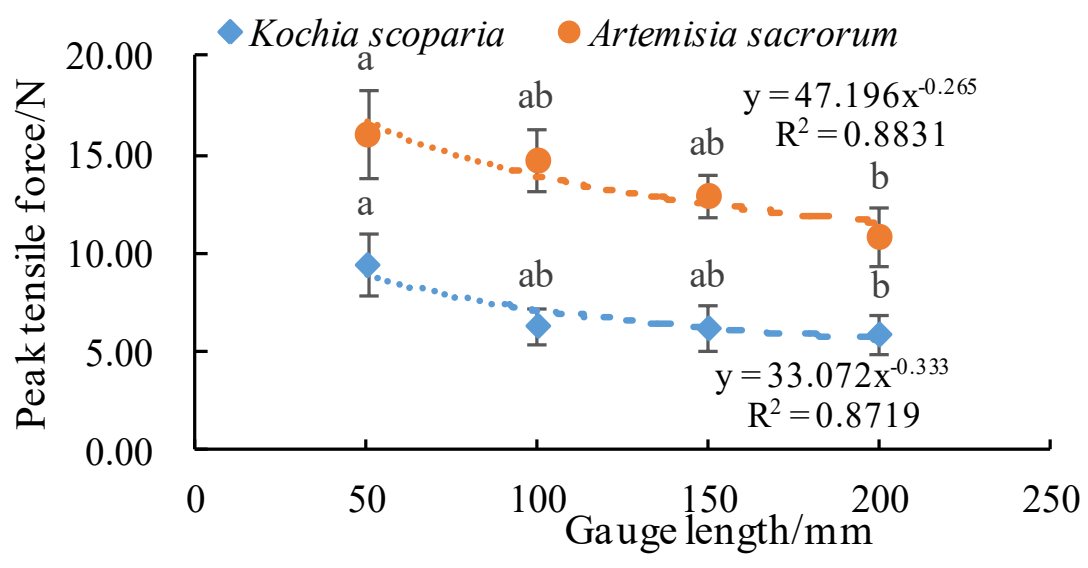

(a)

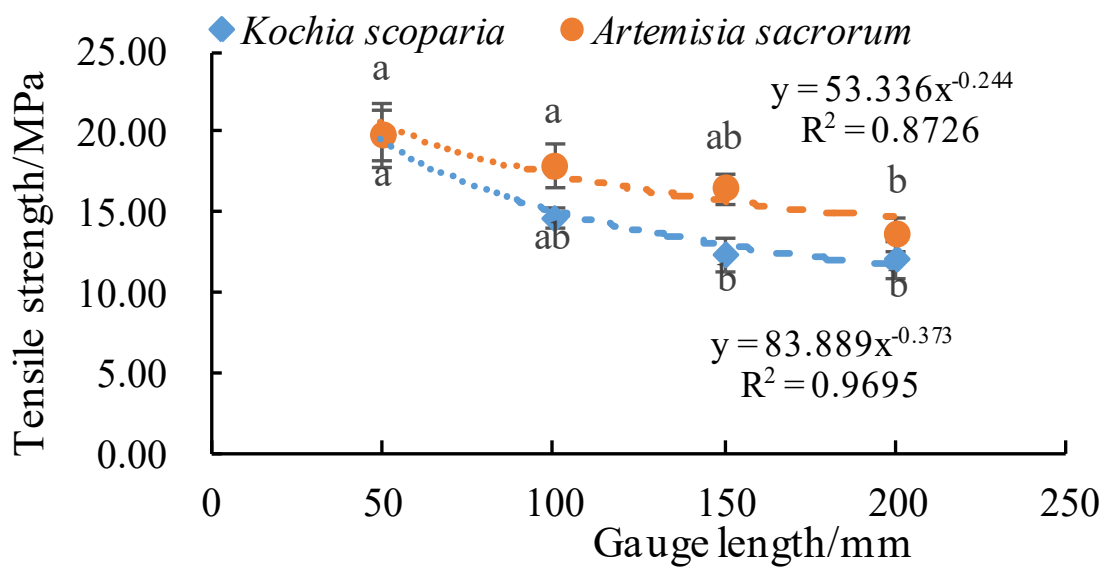

(b)

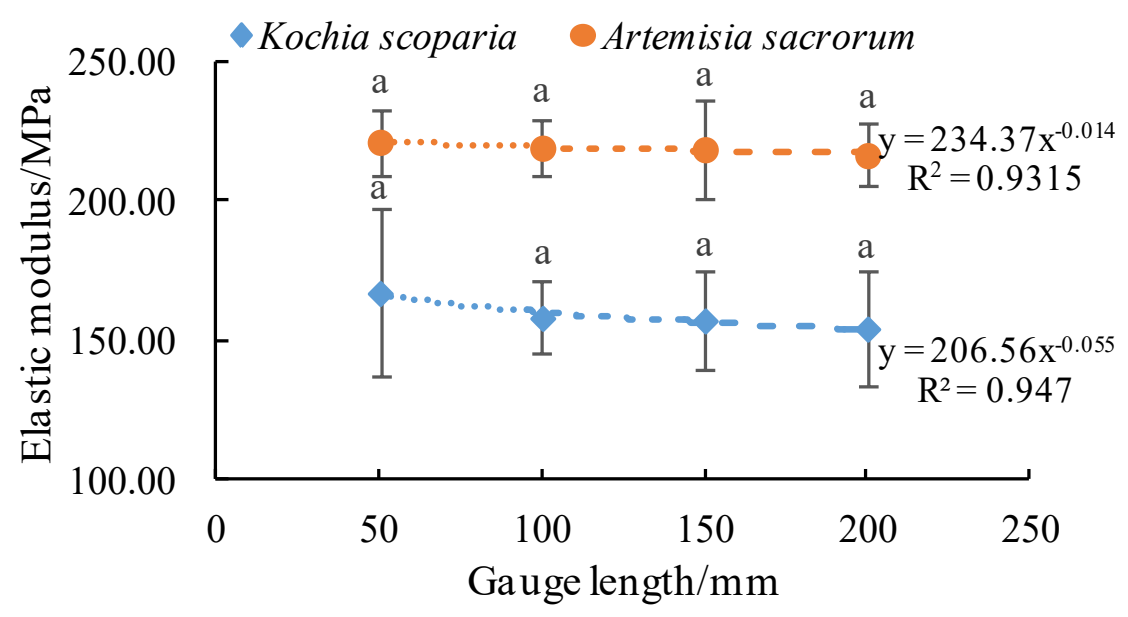

(c)

FIGURE 4. Power function relationships between gauge length and peak tensile force (a), tensile strength (b) and elastic modulus (c). Different lowercase letters show significant difference between different gauge lengths for the same species 


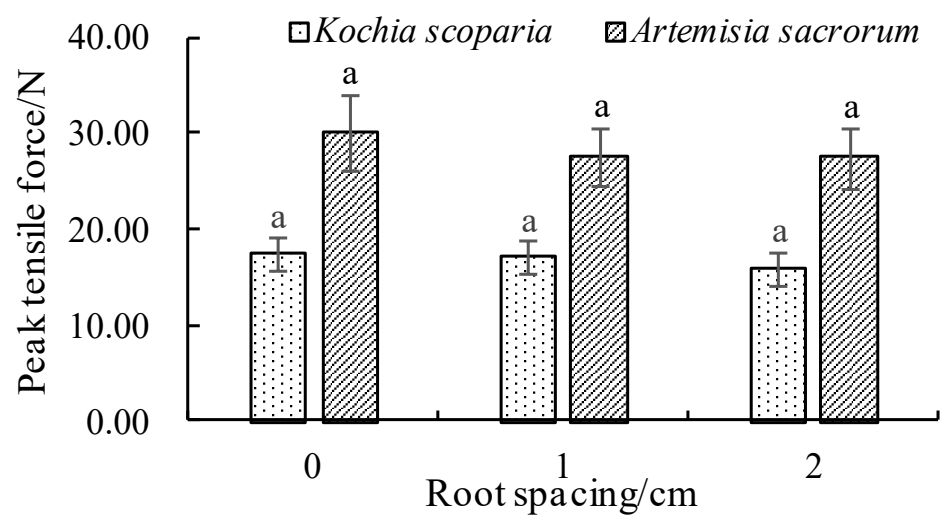

(a)

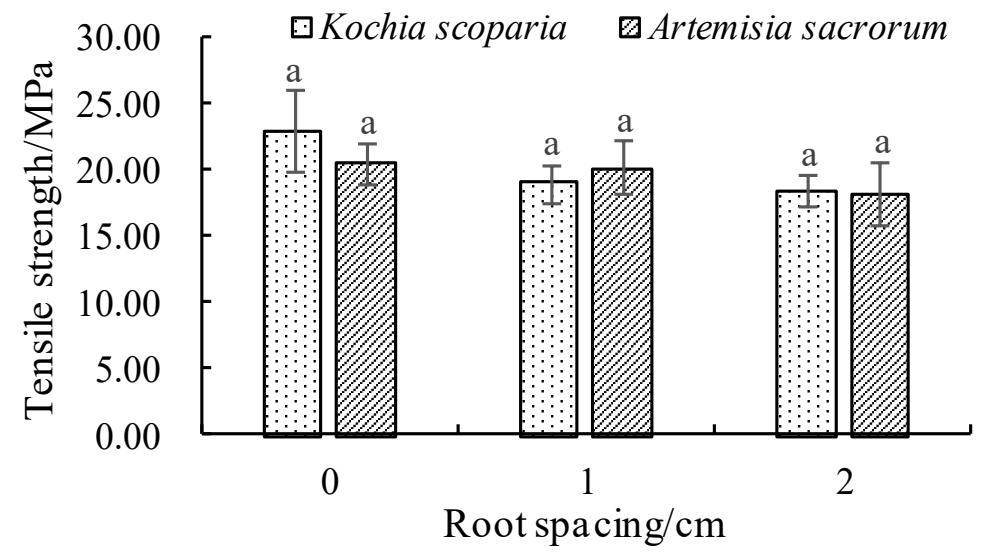

(b)

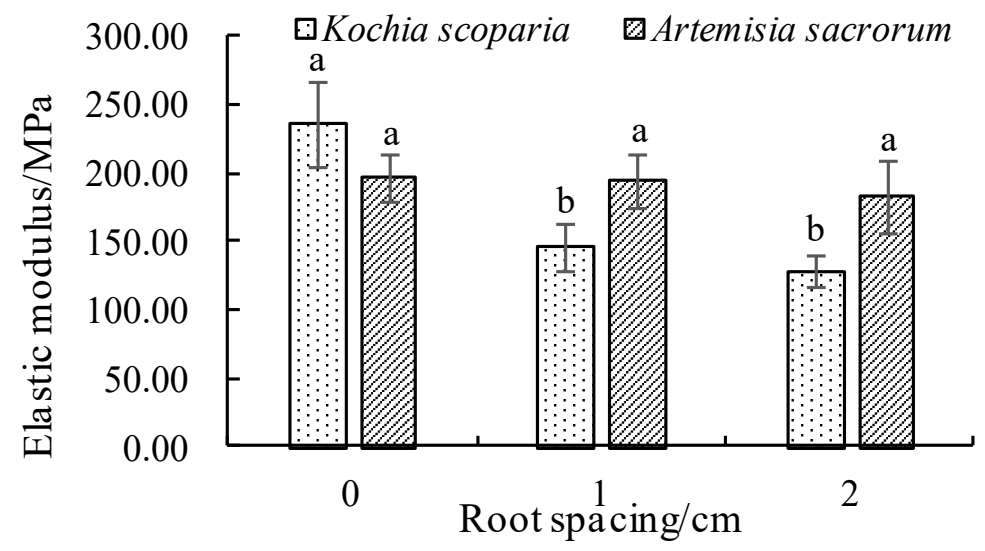

(c)

FIGURE 5. Relationship between root spacing and root tensile force (a), tensile strength (b) and elastic modulus(c). Different lowercase letters show significant difference between different root spacing for the same species 


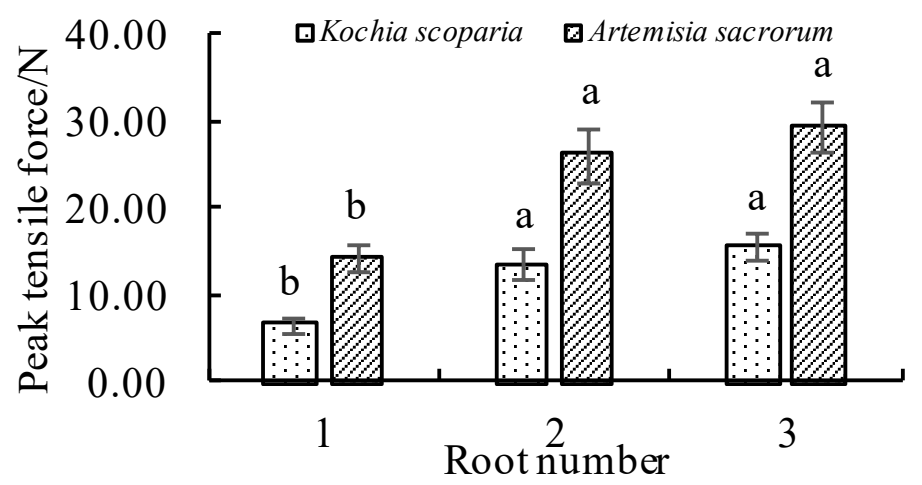

(a)

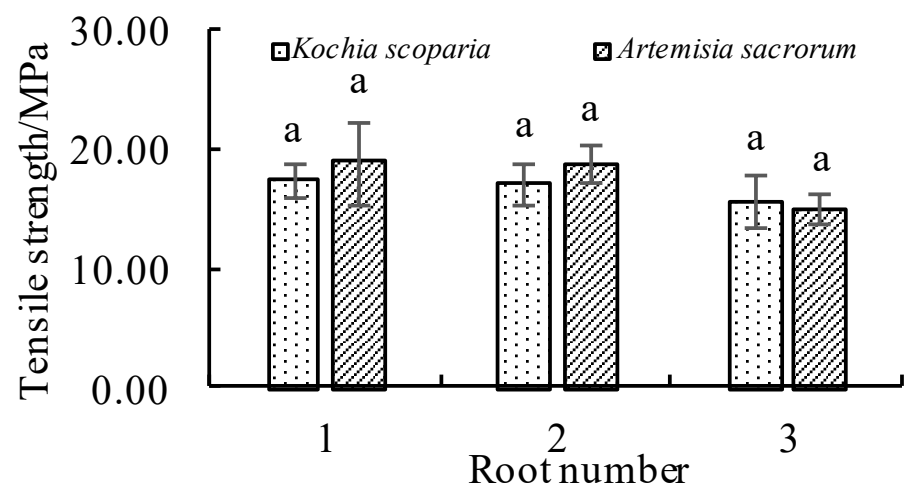

(b)

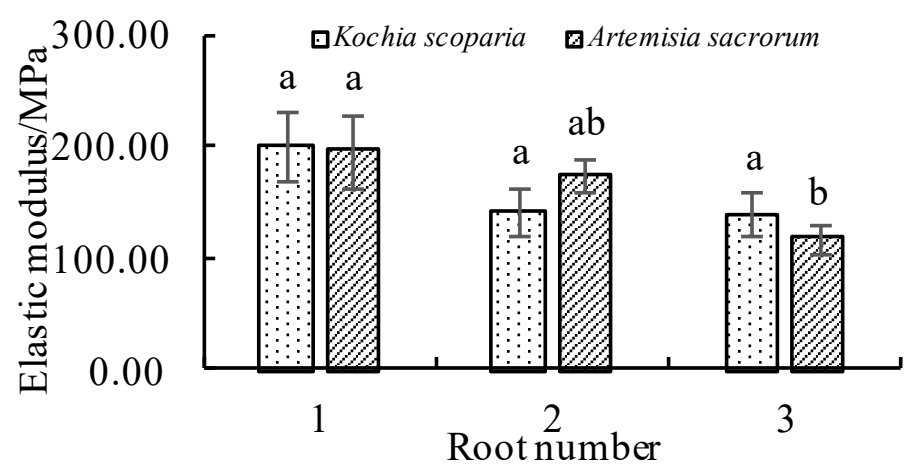

(c)

FIGURE 6. Relationship between root number and peak root tensile force (a), tensile strength (b) and elastic modulus (c). Different lowercase letters show significant difference under different root numbers for the same species 


\section{DISCUSSION}

The root tensile properties (tensile force, tensile strength, and elastic modulus) of the two herbaceous plants were closely related to gauge length, root spacing and root number in this study. Gauge length, root spacing, and root number should be considered in the process of root tensile tests which can obtain root tensile properties for estimates of root reinforcement. The detail relationships between them were discussed in the following.

Root tensile properties were negatively related to gauge length in the power functions. The phenomenon was observed in some previous studies. Zhang et al. (2012) and Yang et al. (2016) studied the root systems of Pinus tabulaeformis and Betula platyphylla, respectively, and they indicated that the root tensile strength decreased with the increase of the gauge length but in a linear trend, which was a bit different from the trend in this research. Generally, roots grow in soil with complex physical and chemical properties, and defects inevitably occur in the roots. The defects are more likely to be present in longer roots (Moreton 1968). Therefore, the longer roots are, the lower their tensile strength could be. However, the function in this study was different, which might be related to different plant species, environmental conditions and the uncertain distribution of defects in roots. In addition, Wang et al. (2012) also pointed out that the elastic modulus of Larix gmelinii decreased with the increase of gauge length, but Pinus tabulaeformis, Betula platyphylla, and Quercus mongolica were positively correlated with gauge length, which was inconsistent with our results. The difference may also be due to the uncertainty of root defects partially. Besides, the different species studied, trees and herbaceous plants, could have different root anatomy and internal tissue composition. If roots are in the ideal status of root reinforcement supposed as the WuWaldron model (Waldron 1977; Wu et al. 1979), shorter roots could produce a larger fixation force on slope soil and keep slope more stable than longer roots. However, in reality, short roots are more likely to be pulled out rather than be broken during the failure process of root-soil composites (Ghestem et al. 2014; Ji et al. 2018). Though long roots suffering from greater soil friction are easier to break than short ones, they could transfer soil shear stress of surface soil to deep stable soil by root tension so as to improve the stability of superficial soil (Fan \& Su 2008; Pallewattha et al. 2019; Saifuddin et al. 2015). Herbaceous plants usually have relative short roots, which is an advantage for herbaceous plants in preventing top soils from surface sliding.
When the gauge length was the same, the tensile force, tensile strength, and elastic modulus all decreased with the increase of root spacing, but the influence of root spacing on tensile force and tensile strength was not significant. The root spacing increases and the roots disperse, which result in the dispersion of root tensile resistance. The two roots with a distance of $0 \mathrm{~cm}$ can be considered as one root with a double diameter, while the two roots that are more than $0 \mathrm{~cm}$ in distance are acting independently. Moreover, the relation between root diameter and tensile force is normally a positive power function (Tosi 2007), so the tensile force of a bigger root with a double diameter is obviously greater than the sum of the tensile force of two smaller roots with a single diameter. Therefore, root tensile force decreases with increasing root spacing. For roots with the same cross-sectional area, the tensile strength decreases correspondingly with root spacing. The influence was only studied considering three spacing $(0,1$, and $2 \mathrm{~cm})$ and ignoring the effect of soil between roots in reality. Giadrossich et al. (2012) pointed out that when the distance between the roots was less than 15 $\mathrm{mm}$, the surrounding soil would interact with each other, thereby affecting the root pulling effect. However, when the distance between the roots was greater than $15 \mathrm{~mm}$, the distance between the roots had no significant influence on the pulling force, which was consistent with our results. The decrease of root spacing would lead to increase of tensile properties. However, too close planting spacing is not a rational choice as overcrowding of roots in soil will intensify competition of water and nutrition between individual plants (Loades et al. 2010; Ng et al. 2016; Ni et al. 2017). Therefore, appropriate planting spacing or planting density could result in proper root spacing and great root tensile properties, and consequent high abilities of root reinforcement and slope stability improvement.

Root number is a key parameter of root-soil composite shear tests, which had been recognized in previous studies (Jiang et al. 2017; Yao et al. 2009). Yao et al. (2009) showed that when root cross-sectional area was fixed, the shear strength of the root-soil composite of Caragana microphylla increased with the increase of the number of the roots. Jiang et al. (2017) found that three vertical roots were more capable than one to provide greater soil reinforcement. In our study, it was also confirmed that root number had an effect on root tensile properties, which was that root tensile force increased with root number, but root tensile strength and elastic modulus decreased with root number. Zhang and $\mathrm{Hu}$ (2014) studied tensile force of Caragana korshinskii roots and 
indicated that the tensile force increased with the number of roots, which was consistent with our study. In addition, the tensile properties of roots did not increase linearly with the number of roots. The root resistance increasing with time was observed in the tensile experiment. When one of the roots broke, the resistance of the rest roots decreased sharply, and then continued to increase. Because the remaining unbroken roots have been used previously, they were not able to achieve the tensile strength when they acted alone. The result was of great importance to the analysis of slope stability. As the number of roots increases, the contact area between roots and soil will increase, which could result in greater effect of soil reinforcement by plant roots. However, deficiency in data of tensile strength and elastic modulus of multiple roots implies that more researches on other herbaceous plants, woody plants may be still needed.

\section{CONCLUSION}

In this study, root tensile characteristics of two herbaceous plants, K. scoparia and A. sacrorum, under three factors (gauge length, root spacing and root number) were studied. The results showed that root tensile properties were dependent on these three factors. Root tensile force, tensile strength and elastic modulus of the two herbaceous plants were negatively correlated with gauge length in power functions. The results showed that gauge length had a significant effect on tensile force and tensile strength, but the effect of gauge length on elastic modulus was not significant. Root tensile properties decreased with increasing gauge length. Herbaceous plants generally having short roots could yield an advantage in reinforcing relatively top soils to prevent them from surface sliding. Root tensile force, tensile strength and elastic modulus decreased slightly with increasing root spacing. Although the influence of root spacing on tensile force, tensile strength and elastic modulus was not significant, the results could still provide some reference value for determining planting density beneficial to soil reinforcement by plant roots. Root tensile force increased but tensile strength and elastic modulus decreased with increasing root number. The results indicated that root tensile properties of multiple roots cannot be simply superimposed and they may overlap slightly when multiple roots work together.

\section{ACKNOWLEDGEMENTS}

This study was supported by the National Natural Science Foundation of China project (No. 31600582),
Research Project Supported by Shanxi Scholarship Council of China (2020-054) and Scientific and Technological Innovation Programs of Higher Education Institutions in Shanxi (2019L0175).

\section{REFERENCES}

Abdi, E. 2018. Root tensile force and resistance of several tree and shrub species of Hyrcanian Forest, Iran. Croatian Journal of Forest Engineering 39(2): 255-270.

Bischetti, G.B., Chiaradia, E.A., D’Agostino, V. \& Simonato, T. 2010. Quantifying the effect of brush layering on slope stability. Ecological Engineering 36(3): 258-264.

Boldrin, D., Leung, A.K. \& Bengough, A.G. 2018. Effects of root dehydration on biomechanical properties of woody roots of Ulex europaeus. Plant and Soil 431(1-2): 347369 .

Cohen, D. \& Schwarz, M. 2017. Tree-root control of shallow landslides. Earth Surface Dynamics 5(3): 451-477.

De Baets, S., Poesen, J., Reubens, B., Wemans, K., De Baerdemaeker, J. \& Muys, B. 2008. Root tensile strength and root distribution of typical Mediterranean plant species and their contribution to soil shear strength. Plant and Soil 305(1-2): 207-226.

Fan, C.C. \& Su, C.F. 2008. Role of roots in the shear strength of root-reinforced soils with high moisture content Ecological Engineering 33(2): 157-166.

Feng, B., Zong, Q.L., Cai, H.B., Chen, Z.K. \& Wang, J.X. 2019. Calculation of increased soil shear strength from desert plant roots. Arabian Journal of Geosciences 12(16): 12.

Ghestem, M., Veylon, G., Bernard, A., Vanel, Q. \& Stokes, A. 2014. Influence of plant root system morphology and architectural traits on soil shear resistance. Plant and Soil 377(1-2): 43-61.

Giadrossich, F., Schwarz, M., Cohen, D., Preti, F. \& Or, D. 2012. Mechanical interactions between neighbouring roots during pullout tests. Plant and Soil 367(1-2): 391-406.

Hales, T.C. \& Miniat, C.F. 2017. Soil moisture causes dynamic adjustments to root reinforcement that reduce slope stability. Earth Surface Processes and Landforms 42(5): 803-813.

Hollis, L.O. \& Turner, R.E. 2019. The tensile root strength of spartina patens varies with soil texture and atrazine concentration. Estuaries and Coasts 42(6): 1430-1439.

Hubble, T.C.T., Airey, D.W., Sealey, H.K., De Carli, E.V. \& Clarke, S.L. 2013. A little cohesion goes a long way: Estimating appropriate values of additional root cohesion for evaluating slope stability in the Eastern-Australian highlands. Ecological Engineering 61: 621-632.

Hudek, C., Sturrock, C.J., Atkinson, B.S., Stanchi, S. \& Freppaz, M. 2017. Root morphology and biomechanical characteristics of high altitude alpine plant species and their potential application in soil stabilization. Ecological Engineering 109: 228-239. 
Ji, X., Cong, X., Dai, X., Zhang, A. \& Chen, L. 2018. Studying the mechanical properties of the soil-root interface using the pullout test method. Journal of Mountain Science 15(4): 882-893.

Jiang, M.J., Zhu, Y.G. \& Xi, B.L. 2017. Investigation into the soil-root composites using distinct element method. In Proceedings of the 7th International Conference on Discrete Element Methods, edited by Li, X., Feng, Y. \& Mustoe, G. Singapore: Springer-Verlag Singapore Pte. Ltd. 188: 10751083.

Jones, K. \& Hanna, E. 2004. Design and implementation of an ecological engineering approach to coastal restoration at Loyola Beach, Kleberg County, Texas. Ecological Engineering 22(4-5): 249-261.

Liu, S., Li, X., Zhu, X. \& Song, F. 2018. Tensile properties of seminal and nodal roots and their relationship with the root diameter and planting density of maize (Zea mays). Crop \& Pasture Science 69(7): 717-723.

Loades, K.W., Bengough, A.G., Bransby, M.F. \& Hallett, P.D. 2010. Planting density influence on fibrous root reinforcement of soils. Ecological Engineering 36(3): 276284.

Mahannopkul, K. \& Jotisankasa, A. 2019. Influence of root suction on tensile strength of Chrysopogon zizanioides roots and its implication on bio-slope stabilization. Journal of Mountain Science 16(2): 275-284.

Moreton, R. 1968. The effect of gauge length on the tensile strength of R.A.E. carbon fibres Fibre Science and Technology 1(4): 273-284.

Ng, C.W.W., Ni, J.J., Leung, A.K., Zhou, C. \& Wang, Z.J. 2016. Effects of planting density on tree growth and induced soil suction. Geotechnique 66(9): 711-724.

Ni, J.J., Leung, A.K. \& Ng, C.W.W. 2019. Influences of plant spacing on root tensile strength of Schefflera arboricola and soil shear strength. Landscape and Ecological Engineering 15(2): 223-230.

Ni, J.J., Leung, A.K., Ng, C.W.W. \& So, P.S. 2017. Investigation of plant growth and transpiration-induced matric suction under mixed grass-tree conditions. Canadian Geotechnical Journal 54(4): 561-573.

Pallewattha, M., Indraratna, B., Heitor, A. \& Rujikiatkamjorn, C. 2019. Shear strength of a vegetated soil incorporating both root reinforcement and suction. Transportation Geotechnics 18: $72-82$.

Pollen, N. 2007. Temporal and spatial variability in root reinforcement of streambanks: Accounting for soil shear strength and moisture. Catena 69(3): 197-205.

Saifuddin, M., Osman, N., Rahman, M.M. \& Boyce, A.N. 2015. Soil reinforcement capability of two legume species from plant morphological traits and mechanical properties. Current Science 108(7): 1340-1347.

Sanchez-Castillo, L., Kubota, T., Cantu-Silva, I., Yanez-Diaz, M., Hasnawir \& Pequeno-Ledezma, M. 2017. Comparisons of the root mechanical properties of three native Mexican tree species for soil bioengineering practices. Botanical Sciences 95(2): 259-269.
Stokes, A., Douglas, G.B., Fourcaud, T., Giadrossich, F., Gillies, C., Hubble, T., Kim, J.H., Loades, K.W., Mao, Z., McIvor, I.R., Mickovski, S.B., Mitchell, S., Osman, N., Phillips, C., Poesen, J., Polster, D., Preti, F., Raymond, P., Rey, F., Schwarz, M. \& Walker, L.R. 2014. Ecological mitigation of hillslope instability: Ten key issues facing researchers and practitioners. Plant and Soil 377(1-2): 1-23.

Tosi, M. 2007. Root tensile strength relationships and their slope stability implications of three shrub species in the northern Apennines (Italy). Geomorphology 87(4): 268283.

Waldron, L. 1977. The shear resistance of root-permeated homogeneous and stratified soil. Soil Science Society of America Journal 41(5): 843-849.

Wang, P., Chen, L. \& Ji, X. 2012. Analysis of stress-strain curves for four common arbor root systems. Bulletin of Soil and Water Conservation 32(3): 17-22.

Wu, T.H., McKinnell III., W.P. \& Swanston, D.N. 1979. Strength of tree roots and landslides on Prince of Wales Island, Alaska. Canadian Geotechnical Journal 16(1): 19-33.

Yang, Y., Chen, L. \& Li, N. 2016. How gauge length and loading rate influence the root tensile strength of Betula platyphylla. Journal of Soil and Water Conservation 71(6): 460-466.

Yao, X., Liu, J., Wang, L., Liu, A. \& Xing, H. 2009. Study on the plant roots to improve shear characteristics in coal mining subsidence area. 3rd International Conference on Bioinformatics and Biomedical Engineering, Beijing. pp. 1-5.

Zavala-Gonzalez, R., Cantu-Silvan, I., Sanchez-Castillo, L., Gonzalez-Rodriguez, H., Kubota, T. \& Hasnawir. 2019. Ten native tree species for potential use in soil bioengineering in northeastern mexico. Botanical Sciences 97(3): 291-300.

Zhang, C., Chen, L., Jiang, J. \& Zhou, S. 2012. Effects of gauge length and strain rate on the tensile strength of tree roots. Trees-Structure and Function 26(5): 1577-1584.

Zhang, C., Zhou, X., Jiang, J., Wei, Y., Ma, J. \& Hallett, P.D. 2019. Root moisture content influence on root tensile tests of herbaceous plants. Catena 172: 140-147.

Zhang, X. \& Hu, X. 2014. Mechanical multiple root effects of Caragana korshinskii roots in frigid and arid-semiarid environment. Hubei Agricultural Sciences 53(19): 46324637.

College of Water Resources Science and Engineering

Taiyuan University of Technology

Taiyuan 030024

China

*Corresponding author; email: zhangchaobo@tyut.edu.cn

Received: 5 April 2020

Accepted: 2 January 2021 